JUSTITIA : Jurnal Ilmu Hukum dan Humaniora

issn cetak :2354-9033 || issn online :2579-9398 || Vol. 1 No. 2 Tahun 2019

http://jurnal.um-tapsel.ac.id/index.php/justitia

\title{
Penerapan Hukum Terhadap Pelaku Kekerasan Dalam Rumah Tangga (Studi Kasus di Pengadilann Negeri Padangsidimpuan) Sutan Siregar
}

Fakultas Hukum UMTS Padangsidimpuan Korespondensi: sutan.siregar@um-tapsel.ac.id

\begin{abstract}
Abstrak
Tindak kekerasan dalam keluarga akan menimbulkan dampak negatif pada anak bahkan keluarga. Faktor penyebab kekerasan dalam rumah tangga secara internal yaitu 1) cemburu, 2) masalah anak, 3) masalah sopan santun, 4) masalah masa lalu, 5) masalah salah paham, 6) masalah tidak memasak, 7)suami mau menang sendiri. Faktor external yaitu 1) masalah keuangan, 2) masalah orang tua, 3) masalah saudara. Sanksi penal, penerapan sanksi penel adalah penerapan sanksi pidana sebagaiman diatur dalam Undang-undang Nomor 23 Tahun 2004 tentang Penghapusan Kekerasan dalam Rumah Tangga. Sanksi non penal, kebijakan non penal berhak mendapatkan: a) perlindungan dari pihak keluarga, kepolisian, kejaksaan, pengadilan, advokat, lembaga sosial atau pihak lainnya baik sementara maupun berdasarkan penetapan perintah perlindungan dari pengadilan; b) pelayanan kesehatan sesuai dengan kebutuhan medis; c) penanganan secara khusus berkaitan dengan setiap proses pemeriksaaan sesuai dengan ketentuan peraturan perundang- undangan; dan e) pelayanan bimbingan rohani.
\end{abstract}

Kata-kata Kunci: Penerapan Hukum; Pelaku; Kekerasan Dalam Rumah Tangga

\begin{abstract}
The acts of violence in the family will have a negative impact on children and even families. Factors that cause domestic violence internally are 1) jealousy, 2) problems of children, 3) problems of courtesy, 4) problems of the past, 5) problems of misunderstanding, 6) problems of not cooking, 7) husbands want to win themselves. External factors are 1) financial problems, 2) parents' problems, 3) your problems. Penal sanctions, the application of penel sanctions are the application of criminal sanctions as regulated in Act Number 23 of 2004 concerning the Elimination of Domestic Violence. Non-penal sanctions, non-penal policies are entitled to: a) protection from family, police, prosecutors, courts, advocates, social institutions or other parties both temporarily and based on the stipulation of protection orders from the court; b) health services according to medical needs; c) handling specifically related to each inspection process in accordance with statutory provisions; and e) spiritual guidance services.
\end{abstract}

Key words: Application of Law; Perpetrators; Domestic Violence 


\section{PENDAHULUAN}

Tindak kekerasan dalam masyarakat sebenarnya bukan suatu hal baru. Kekerasan sering dilakukan dengan salah satu bentuk tindak pidana, seperti yang diatur dalam kitab UndangUndang Hukum Pidana (KUHP) misalnya pencurian dengan kekerasan (Pasal 365 KUHP), penganiayaan (Pasal 351 KUHP), perkosaan (Pasal 285 KUHP) dan seterusnya. Tindak pidana tersebut dilakukan dengan kekerasan atau ancaman kekerasan, sedangkan cara bagaimana kekerasan dilakukan atau alat yang dipakai, masing-masing tergantung pada kasus yang timbul. Jadi, sifatnya kasuistis.Perbuatan tersebut dapat menimpa siapa saja, baik laki-laki maupun perempuan, dari anak-anak sampai dewasa. Namun, yang menarik perhatian publik adalah kekerasan yang menimpa kaum perempuan (istri)

Terjadinya kekerasan dalam keluarga akan menimbulkan dampak yang negatif pada anak bahkan keluarga itu sendiri, seperti istri menuntut untuk bercerai karena tidak tahan dengan perilaku suami yang keras. Gunarsa (2007) berpendapat bahwa perbedaan pertentangan dan kekecewaan baik dalam segi materi, mental maupun seksual telah membentuk dinding pemisah antara suami dan istri.Ketidaksesuaian ini member kesempatan bagi terbentuknya hubungan segitiga atau lebih.Hubungan yang tidak wajar lagi antara beberapa individu ini memperbesar dinding pemisah dan merusak kutuhan keluarga. Penderitaan ini akan lebih dirasakan oleh kaum istri, karena istri merupakan penampung emosi dari suami.

Keutuhan dan kerukunan rumah tangga yang bahagia, aman, tentram, dan damai merupakan dambaan setiap orang dalam rumah tangga. Negara Republik I ndonesia adalah negara yang berdasarkan Keutuhan Yang Maha Esa dijamin oleh Pasal 29 Undang-Undang Dasar Negara RI Tahun 1945. Dengan demikian, setiap orang dalam lingkup rumah tangga dalam melaksanakan hak dan kewajibannya harus didasari oleh agama .hal ini perlu terus ditumbuh kembangkan dalam rangka membangun keutuhan rumah tangga.

Untuk mewujudkan keutuhan dan kerukunan tersebut, sangat tergantung pada setiap orang dalam lingkup rumah tangga, terutama kadar kualitas perilaku dan pengendalian diri setiap orang dalam lingkup rumah tangga tersebut. Keutuhan dan kerukunan rumah tangga dapat terganggu jika kualitas dan pengendalian diri tidak dapat dikontrol, yang pada akhirnya dapat terjadi kekerasan dalam rumah tangga sehingga timbul ketidakamanan.

Seperti salah satu lembaga hukum yang dibentuk oleh Asosiasi Perempuan Indonesia yang menentang keras adanya kekerasan dalam rumah tangga (KDRT), yang meneropong bahwa kekerasan dalam KDRT menjadikan wanita sebagai korban itu maka lahirlah Undang- Undang No 23 Tahun 2004 tentang KDRT 
yang mengecam setiap kekerasan yang terjadi dalam rumah tangga. Melihat hal tersebut, perlu dikaji bagaimana kajian kebijakan kriminal pada kekerasan dalam rumah tangga.

Adapun jumlah perkara tindak pidana kekerasan dalam rumah tangga di Pengadilan Negeri Padangsidimpuan adalah sebagai berikut:

Tabel 1Jumlah Perkara Tindak Pidana Kekerasan Dalam Rumah Tangga di Pengadilan Negeri Padangsidimpuan

\begin{tabular}{|c|c|c|}
\hline No & Tahun & Jumlah \\
\hline 1 & 2007 & 15 \\
\hline 2 & 2008 & 12 \\
\hline 3 & 2019 & 20 \\
\hline 4 & 2010 & 19 \\
\hline 5 & 2011 & 13 \\
\hline & Jumlah & 79 \\
\hline
\end{tabular}

Sumber : Pengadilan Negeri Padangsidimpuan Tahun 2018

Tabel diatas menunjukkan bahwa angka kasus kekerasan dalam rumah tangga yang ditangani Pengadilan Negeri Padangsidimpuan cukup tinggi.Hal tersebut menunjukkan bahwa penanggulangan kekerasan dalam rumah tangga masih mengalami hambatan.

\section{PEMBAHASAN}

\section{A. Sanksi Penal}

G. Peter Hoefnagelsmengemukakan, bahwa ilmu pengetahuan kebijakan kriminal merupakan ilmu pengetahuan penangguiangan kejahatan. Selanjutnya dengan mendasarkan pada pendapat Marc Ancel, ia mengemukakan, bahwa : "crimina! policy is the rational organization of the soscial reaction to crime". Hoefnagels juga mengenmukakan, bahwa kebijakan kriminal sebagai ilmu pengetahuan kebijakan adalah bagian dari kebijakan yang lebih besar, yaitu kebijakan penegakan hukum. Sementara itu, kebijakan penegakan hukum merupakan bagian dari kebijakan sosial.

Kebijakan kriminal atau upaya penanggulangan kejahatan pada hakikatnya merupakan bagian integral dari upaya perlindungan masyarakat Kekerasan pada Anak: Bentuk, Penanggulangan, dan... - Sudaryono (social defence) dan upaya mencapai kesejahteraan masyarakat (social welfare).Oleh karena itu dapat dikatakan, bahwa tujuan akhir atau tujuan utama dari kebijakan kriminal ialah perlindungan masyarakat untuk mencapai kesejahteraan masyarakat. Dengan demikian dapatlah dikatakan, bahwa kebijakan kriminal pada hakikatnya merupakan bagian integral dari kebijakan sosial, yaitu usaha yang rasional untuk men-capai kesejahteraan masyarakat. 
Sebagai usaha penanggulangan kejahatan, kebijakan kriminal dapat mengejawantah dalam berbagai bentuk.Pertama, yakni bersifat represif yang menggunakan sarana penal, yang sering disebut sebagai sistem peradilan pidana (criminal justice sistem.Dalam hal ini secara luas sebenarnyamencakup pula proses kriminalisasi. Kedua, yakni berupa usaha-usaha prevention withaout punishment (tanpa menggunakan sarana penal), dan yang ketiga, adalah pendayagunaan usaha-usaha pembentukan opini masyarakat tentang kejahatan dan sosialisasi hukum melalui mass media secara luas.Bila dikaitkan dengan kekerasan dalam rumah tangga, maka penerapan sanksi penal adalah ketentuan sanksi pidana pada UndangUndang Nomor 23 Tahun 2004 tentang Penghapusan Kekerasan Dalam Rumah Tangga.

\section{B. Penerapan Hukum di Pengadilan Negeri Padangsidimpuan}

Peran masyarakat di wilayah hukum Padangsidimpuan masih sangatlah rendah, karena masyarakat masih mengaggap bahwa sikap kekerasan dalam rumah tangga merupakan masalah pribadi rumah tangga yang bersangkutan.Untuk menyikapi hal tersebut tentunya diperlukan upaya seperti sosialisasi dan penyuluhan hukum secara berkesinambungan kepada masyarakat agar memahami maksud dan tujuan dari Undang-undang kekerasan dalam rumah tangga.

Adapun hambatan lainnya terhadap penarapan hukum terhadap kekerasan dalam rumah tangga yaitu:

1. Undang-undang kekerasan dalam rumah tangga tidak mengadopsi pasal-pasal dalam KUHP

2. Belum ada kata standar tentang legalitas suami-istri 3. Masih bersifat penafsiran.

Maka daripada itu Lifiana Tanjung mengatakan bahwasanya perlu segera direvisi undang-undang kekerasan dalam rumah tangga, karena masih banyak kelemahan dalam penerapannya.Jika dilihat dari keterangan penerapan hukum di Pengadilan Negeri Padangsidimpuan, dapat dikatakan bahwasanya ada permasalahan di penerapan undang-undang kekerasan dalam rumah tangga.Hal tersebut dikarenakan terdapat kelemahan di undang-undang tersebut.Maka daripada itu perlu kiranya merevisi undang-undang tersebut.

\section{Hambatan-Hambatan dalam Penanganan Kekerasan Dalam Rumah Tangga}

Hambatan dalam penanganan kekerasan dalam rumah tangga dimulai pada saat penyidikan. Penyidik Polisi (Polri) menghadapi kendala karena masih kuatnya anggapan masyarakat bahwa kekerasan dalam rumah tangga adalah persoalan pribadi 
atau persoalan rumah tangga, sehingga tidak layak dicampuri oleh orang lain atau polisi. Perempuan (istri) karena memiliki perasaan hati nurani yang lembut dan kentalnya adat dan budaya Timur, menjadi tidak tega memberi balasan kepada suami atau mantan suami dengan melaporkan perbuatannya kepada Polisi, meskipun telah menyakiti dan menyiksanya baik secara fisik, maupun psikis.

Pada umumnya fenomena kasus kekerasan dalam rumah tangga mempunyai spesifikasi sendiri, antara lain.sebagai berikut.

1. Terjadinya tindak kekerasan lebih banyak diketahui oleh pelaku dan korban saja, sehingga kurang adanya saksi maupun alat bukti lainnya yang memenuhi Pasal 183 dan 184 KUHAP.

2. Pihak korban enggan melaporkan kasusnya karena merasa tabu dan beranggapan akan membuka aib keluarga sendiri terutama terhadap kasus yang berhubungan dengan seksual.

3. Bagi korban yang mau melapor dan perkaranya memenuhi syarat formil maupun materiil, tidak jarang berusaha mencabut kembali, karena merasa ia sangat memerlukan masa depan bagi anak-anaknya dan masih menginginkan rumah tangganya dapat dibangun kembali.

4. Keterlambatan laporan dari korban atas terjadinya kasus kekerasan dalam rumah tangga, akan berpengaruh terhadap tingkat kesukaran penyidik dalam melakukan proses penyidikan, terutama pengumpulan saksi dan barang bukti.

Selanjutnya dalam setiap langkah menuju suatu perubahan dan perbaikan seringkali mendapat hambatan atau halangan seperti disebutkan di muka.Demikian pula dengan masalah kekerasan dalam rumah tangga, meskipun sudah dibuat undangundang khusus yang dapat dipergunakan untuk menangani kasus kekerasan dalam rumah tangga, namun dalam kenyataannya masih sering terjadi tindak kekerasan dalam rumah tangga. Selain hambatan dalam proses penyidikan, terdapat hambatan yang dapat berasal dari faktor intern maupun faktor ekstern artinya bida datang dari korban kekerasan sendiri maupun dari keluarga korban, masyarakat dan Negara.

Berikut akan diuraikan satu per satu hambatan dalam penanganan kasus-kasus kekerasan dalam rumah tangga, sebagai berikut.

1. Hambatan dari korban dapat terjadi karena:

a. Korban tidak mengetahui bahwa tindakan kekerasan yang dilakukan oleh suami merupakan perbuatan pidana atau perbuatan yang dapat dihukum. Oleh karena itu, korban tidak melaporkan tindak kekerasan yang dialaminya;

b. Korban membiarkan tindakan kekerasan terhadap dirinya sampai berlarut-larut. Hal ini bisa disebabkan oleh korban berpendapat bahwa tindakan suami akan berubah; 
c. Korban berpendapat apa yang dialaminya adalah takdir atau nasibnya, sebagai istri. Hal ini dapat terjadi karena adanya pendapat bahwa seorang istri harus "bekti" (setiap dan mengabdi) pada suami;

d. Korban memepunyai ketergantungan secara ekonomi pada pelaku tindak kekerasan;

e. Korban mempertahankan status sosialnya, sehingga kalau sampai tindak kekerasan yang terjadi dalam rumah tangganya diketahui oleh orang lain, akan memperburuk status sosial keluarganya di dalam masyarakat;

f. Korban takut ancaman dari suami;

g. Korban khawatir keluarga akan menyalahkan dirinya karena dianggap tidak dapat menyelesaikan masalah rumah tangganya sendiri;

h. Korban terlambat melaporkan tindakan kekerasan yang dialami, sehingga bukti-bukti fisik sudah hilang.

2. Hambatan dapat dilakukan oleh keluarga korban, karena kekerasan dalam rumah tangga adalah aib keluarga yang harus ditutupi agar tidak diketahui oleh masyarakat. Alasan yang lain adalah karena tindak kekerasan yang terjadi dalam rumah tangga merupakan urusan domestik atau urusan intern keluarga.

3. Hambatan yang lain datang dari masyarakat. Memang masih ada pendapat yang menganggap keekrasan dalam rumah tangga adalah urusan keluarga bukan merupakan kejahatan yang dapat diselesaikan melalui jalur hukum. Pendapat demikian masih mewarnai berbagai kalangan dalam masyarakat, sehingga akan merupakan hambatan bagi penegakan hukum di bidang tindak kekerasan dalam rumah tangga.

4. Hambatan dari negara

a. Hambatan ini berupa ketentuan bahwa biaya visum et repertum harus dikeluarkan oleh korban. Bagi korban yang tidak mampu, hal ini merupakan hambatan dalam mencari keadilan.

b. Selain itu dimasukkannya kekerasan fisik, psikis dan seksual yang dilakukan oleh suami terhadap istri, kedalam delik aduan, sangat membatasi ruang gerak istri. Meskipun dalam undang-undang tidak disebutkan delik aduan absolut atau delik aduan relatif tetap saja menempatkan istri pada posisi subordinatif. Hal ini tercantum dalam Pasal 51, 52 dan 53 Undang-Undang Nomor 23 Tahun 2004. Padahal pada awalnya sudah ditentukan bahwa kekerasan dalam rumah tangga merupakan suatu delik, suatu perbuatan pidana yang dapat diproses secara hukum.

Berbagai hambatan tersebut mengakibatkan korban menjadi sulit untuk mendapatkan keadilan.Adapun bagi suami yang 
melakukan tindak kekerasan seakan-akan dilindungi dengan adanya ketentuan tersebut.Karena dalam delik aduan relatif hanya korban atau keluarganya yang berhak mengadukan perbuatan pelaku, sedangkan dalam delik aduan absolut hanya korban yang berhak melakukan pengaduan. Dalam undang-undang tidak dijelaskan apakah Pasal 44 ayat (4), Pasal 45 ayat (2), dan Pasal 46 Undang-Undang Nomor 23 Tahun 2004 termasuk delik aduan absolut atau delik aduan relatif. Dengan demikian, perempuan yang menjadi korban kekerasan dalam rumah tangga tetap berada dalam posisi yang lemah di mata hukum.

\section{PENUTUP}

Hasil penelitian menunjukkan bahwa pengaturan hukum tentang kekerasan dalam rumah tanggadiatur di dalam UndangUndang Nomor 23 Tahun 2004 tentang Penghapusan Kekerasan Dalam Rumah Tangga. Di dalam konsiderannya, undang-undang ini lahir dikarenakan bahwa setiap warga negara berhak mendapatkan rasa aman dan bebas dari segala bentuk kekerasan sesuai dengan fa(safah Pancasila dan Undang-Undang Dasar Negara Repubiik Indonesia Tahun 1945. Segala bentuk kekerasan, terutama kekerasan dalam rumah tangga, merupakan pelanggaran hak asasi manusia dan kejahatan terhadap martabat kemanusiaan serta bentuk diskriminasi yang harus dihapus.Dan Undang-Undang Nomor 1 Tahun 1974 tentang Perkawinan menerangkan bahwa tujuan perkawinan adalah membentuk keluarga bahagia dan kekal.Kekerasan dalam rumah tangga terjadi karena ada faktor pemicu atau pendorong.

\section{Daftar Bacaan}

\section{a. Buku}

Adler, Freda, et.al, (1995). Criminology, Second Edition.USA: McGraw - Hill Ali, Achmad, 1996, Menguak Tabir Hukum (Suatu Kajian Filosofis dan Sosiologis), Candra Utama, Jakarta.

Arief, Barda Nawawi, 1998, Beberapa Aspek Kebijakan Penegakkan dan Pengembangan Hukum Pidana, Citra Aditya Bakti, Bandung.

\section{b. Peraturan Perundang-undangan}

Kitab Undang-Undang Hukum Pidana Undang-Undang Dasar 1945

Undang-Undang Nomor 23 Tahun 2004 tentang Penghapusan Kekerasan Dalam Rumah Tangga

c. Putusan Pengadilan

Putusan Nomor 351/Pid.B/2011/PN.PSP 